\title{
MICROPROPAGATION OF KALANCHOE TUBIFLORA (HARVEY) HAMET
}

\author{
MIKROROZMNAŻANIE KALANCHOE TUBIFLORA (HARVEY) HAMET
}

\begin{abstract}
Summary. Kalanchoe tubiflora (Harvey) Hamet is a succulent plant native to Madagascar. Due to its unique morphology, it is a popular ornamental species. However, owing to some valuable metabolites it can also be used in tumor suppression. The present work describes a simple propagation method of $K$. tubiflora. The stem fragments of $K$. tubiflora were disinfected with the following sodium hypochlorite concentrations: $0.2 \%$ (for 10 or $20 \mathrm{~min}$ ), $0.4 \%$ (10 or $20 \mathrm{~min}$ ) and $0.6 \%$ (10 or $20 \mathrm{~min}$ ). Next the single-node explants were inoculated on a hormone-free MS medium. The produced plants were transferred to soil and grown in a greenhouse. The applied disinfection procedures were successful. The regeneration of propagules was observed. The average number of new microshoots produced from one explant varied from about 20 to even 52. All microshoots regenerated adventitious roots without transferring them to a rooting medium. The plantlets were successfully acclimatized and continued their growth in the greenhouse.
\end{abstract}

Key words: acclimatization, caulogenesis, disinfection, in vitro culture, organogenesis, rooting, single-nodes, succulents

\section{Introduction}

Kalanchoe tubiflora (Harvey) Hamet (syn. Kalanchoe delagoensis Eckl. et Zeyh, Crassulaceae) is a succulent native to Madagascar (Johnson, 1948). Due to its original habit, beautiful flowers, and high resistance to drought it is a popular ornamental plant. The species is characterised by a high level of cardiac glycosides. Therefore, it is gaining importance in pharmacy and medicine. Recent studies have also shown that due to the high content of metabolites of antimitotic activity, the species may be valuable in anticancer therapy (Garcês and Sinha, 2009; Hsieh et al., 2012). Moreover, it is used to treat wounds, allergies, and skin diseases (Hsieh et al., 2013). This omni-potential fea- 
Kulus, D. (2015). Micropropagation of Kalanchoe tubiflora (Harvey) Hamet. Nauka Przyr. Technol., 9, 1, \#14. DOI: 10.17306/J.NPT.2015.1.14

ture may cause an increase in the demand for the species. Therefore, the development of efficient multiplication protocols of $K$. tubiflora appears to be justified.

Nowadays in vitro tissue culture-based micropropagation is considered to be the most efficient plant reproduction method. The techniques found wide employment with several succulents (Saifullah et al., 2006; Wojciechowicz, 2009).

The aim of the study was to develop a cheap and efficient reproduction method of Kalanchoe tubiflora under in vitro conditions. According to the author's knowledge this is the first paper about micropropagation of $K$. tubiflora.

\section{Materials and methods}

Material used consisted of single-node fragments of Kalanchoe tubiflora with cutoff leaves, derived from shoots of plants grown in a greenhouse.

\section{Disinfection of explants}

Disinfection of explants was conducted in December. The initial stage involved rinsing shoot segments under running water and then in sterile water with a drop of detergent. Next the explants were disinfected for $2 \mathrm{~s}$ with $70 \%$ ethanol and immersed for 10 or $20 \mathrm{~min}$ in the sterilizing agent - sodium hypochlorite $(0.2,0.4$ or $0.6 \% \mathrm{NaOCl})$. Then the explants were rinsed $3 \times$ in sterile distilled water $(10 \mathrm{~min})$.

\section{Organogenesis in vitro}

Disinfected single-node segments were placed vertically on the modified MS (Murashige and Skoog, 1962) medium supplemented with $0.09 \mathrm{M}$ (standard 3\% w/v) sucrose, and $330 \mathrm{mg} \cdot 1^{-1} \quad \mathrm{CaCl}_{2} \cdot 6 \mathrm{H}_{2} \mathrm{O}, 13.9 \mathrm{mg} \cdot 1^{-1} \quad \mathrm{FeSO}_{4} \cdot 7 \mathrm{H}_{2} \mathrm{O}$ and $20.6 \mathrm{mg} \cdot 1^{-1}$ $\mathrm{Na}_{2}$ EDTA $\cdot 2 \mathrm{H}_{2} \mathrm{O}$, and solidified with $8 \mathrm{~g} \cdot \mathrm{l}^{-1}$ agar. The nutrient medium was poured out in $350 \mathrm{ml}$ glass jars $(40 \mathrm{ml}$ of medium, five explants per jar - a single replication, three replications used) and $\mathrm{pH}$ was adjusted to 5.8 prior autoclaving.

All the explants were grown in a growth room at $24^{\circ} \mathrm{C} \pm 2{ }^{\circ} \mathrm{C}$, with $16 \mathrm{~h}$ of cool white fluorescent light at photosynthetic photon flux density $21.33 \mu \mathrm{mol} \cdot \mathrm{m}^{-2} \cdot \mathrm{s}^{-1}$.

During the experiment the plants were not treated with any PGRs. There were also no additional passages of explants conducted.

After the first 14 days of culture the efficiency of disinfection was recorded. The origin of contaminations was based on the morphological observations of the colonies (smooth and glistening were considered to be bacterial, while fussy - fungal). During the next six months the possibility of further growth/regeneration of roots and shoots was described.

\section{Acclimatization}

In July 2013 the produced microshoots were counted, and then transferred to ex vitro conditions (60-120 microshoots from each factorial combination). The plants were placed in plastic pots (18 cm in diameter) filled with a non-sterile Gramoflor substrate. The plants were grown in a greenhouse in the natural light rhythm. To prevent the plants 
Kulus, D. (2015). Micropropagation of Kalanchoe tubiflora (Harvey) Hamet. Nauka Przyr. Technol., 9, 1, \#14. DOI: 10.17306/J.NPT.2015.1.14

from dehydration and sunburn, pots were covered with white nonwoven fabric during the first month of cultivation. Over the next three months the acclimatization efficiency (percentage of growing plants) was specified. In order to compare the morphology of the plants propagated traditionally and in vitro, control plants (propagated in vivo by propagules) were grown in the same greenhouse.

\section{Statistical analysis}

The percentage data were arcsine transformed according to Freeman-Tukey procedure before analysis. The results were subjected to analysis of variance (ANOVA; all effects were considered random) and the comparisons of means were made according to Tukey's Multiple Comparison Test $(\mathrm{p} \leq 0.05)$ by using ANALWAR-5.2-FR tools. Within the experiment six factorial combinations were studied: two times of disinfection $\times$ three $\mathrm{NaOCl}$ concentrations in three replications.

\section{Results and discussion}

\section{Disinfection of explants}

All of the treated explants survived disinfection. After two weeks of culture the mean disinfection efficiency reached $77.1 \%$. Such high results are especially satisfying since the initiation of culture was carried out in autumn/winter, when the disinfection efficiency is usually the lowest. The most intensive development of contaminations was observed by the end of the first and at the beginning of the second week. Significantly more material loss $(68.2 \%)$ was caused by bacteria. Fungal contaminations accounted for only $31.8 \%$.

There were significant differences between various disinfection protocols in terms of a total number of infections (Table 1). The highest disinfection efficiency (percentage of non-infected explants) was observed after a 10 -minute treatment with $\mathrm{NaOCl}$, regardless of its concentration. Neither the concentration of $\mathrm{NaOCl}$, nor the time of exposition

Table $1 . \mathrm{NaOCl}$ concentration and disinfection time effect on the share of infected explants after 14-day culture (\%)

Tabela 1 . Wpływ stężenia $\mathrm{NaOCl}$ i czasu dezynfekcji na udział zakażonych eksplantatów 14 dni po inicjacji kultury $(\%)$

\begin{tabular}{|c|c|c|c|c|}
\hline \multirow{2}{*}{$\begin{array}{c}\text { Time } \\
\text { Czas } \\
(\mathrm{min})\end{array}$} & $0.2 \%$ & $0.4 \%$ & $0.6 \%$ & $\bar{x}(\%)$ \\
\cline { 2 - 5 } & $32.2 \pm 1.8 \mathrm{aA}$ & $26.0 \pm 2.0 \mathrm{bA}$ & $19.9 \pm 1.7 \mathrm{bA}$ & $24.5 \pm 4.14 \mathrm{a}$ \\
10 & $37.2 \pm 2.2 \mathrm{aB}$ & $52.3 \pm 3.1 \mathrm{aA}$ & $39.5 \pm 2.3 \mathrm{aB}$ & $44.2 \pm 4.21 \mathrm{~b}$ \\
20 & $34.7 \pm 1.85 \mathrm{~B}$ & $43.5 \pm 9.09 \mathrm{~A}$ & $29.7 \pm 5.78 \mathrm{~B}$ & \\
\hline $\bar{x}$ & & \multicolumn{4}{|c|}{$\mathrm{NaCl}$ concentration - Stężenie NaOCl } \\
\hline
\end{tabular}

Standard deviations followed by the same letters are not significantly different at $\mathrm{p} \leq 0.05$. Small letters refer to the disinfection time, capital letters refer to the $\mathrm{NaOCl}$ concentration, $\bar{x}$ - mean.

Odchylenia standardowe oznaczone tymi samymi literami nie różnią się istotnie przy $\mathrm{p} \leq 0,05$. Małe litery odnoszą się do czasu dezynfekcji, duże litery odnoszą się do stężenia $\mathrm{NaOCl}, \bar{x}$ - średnia. 
Kulus, D. (2015). Micropropagation of Kalanchoe tubiflora (Harvey) Hamet. Nauka Przyr. Technol., 9, 1, \#14. DOI: 10.17306/J.NPT.2015.1.14

significantly affected the development of fungal contaminations (data not shown). However, longer disinfection with $0.2 \% \mathrm{NaOCl}$ resulted in a significantly more frequent bacteria occurrence (data not shown). The observed loss of material due to bacteria development is quite uncommon, since usually fungal contaminations are the main propulsion in micropropagation. This may indicate the presence of endophytes - microorganisms living in the body of $K$. tubiflora.

The bacterial endophytes hypothesis is supported by the fact that more contaminations were observed after a longer (20-minute) disinfection. Prolonged exposure to $\mathrm{NaOCl}$ could lead to damage of the plants tissues and, consequently, more frequent spread of bacterial colonies.

\section{Caulogenesis in vitro}

First signs of growth (axillary bud development) were visible already six days after culture initiation. From the obtained plantlets, secondary microshoots were produced in two ways: axillary shoots development (both single and multiple, Fig. 1 A-D) and more frequent - direct regeneration of adventitious shoots from distal leaves edges (Fig. $1 \mathrm{E}-\mathrm{H}$ ).
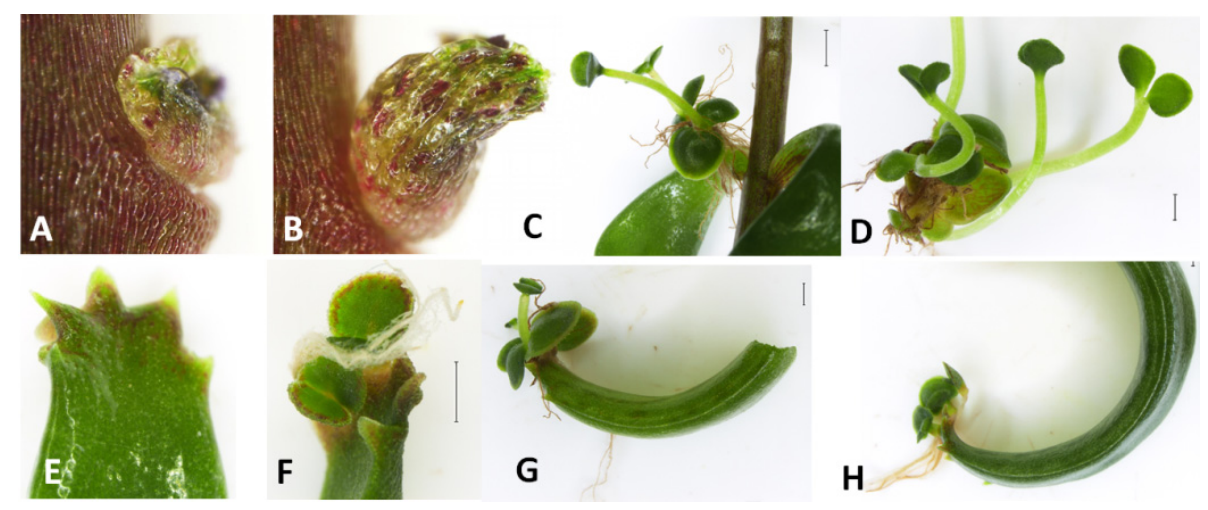

Fig. 1. Development of auxillary (A-D) and adventitious (E-H) shoots of Kalanchoe tubiflora (from leaf axil/leaf edge, respectively) with roots $(1 \mathrm{bar}=1 \mathrm{~mm})$

Rys. 1. Rozwój pędów bocznych (A-D) i przybyszowych (E-H) Kalanchoe tubiflora (odpowiednio z kąta/brzegu liścia) wraz z korzeniami (1 odcinek $=1 \mathrm{~mm})$

A relationship between the disinfection procedure and the efficiency of caulogenesis in vitro was recorded. The greatest number of shoots per explant was produced after applying $0.4 \% \mathrm{NaOCl}$ (43.5), while the smallest (29.7) with $0.6 \%$ (Table 2). Longer disinfection stimulated organogenesis (44.2 microshoots per explant) in comparison to the shorter path (24.5). A significant interaction between these two factors was observed: the highest (52.3, maximum 64.4) after 20 -minute disinfection with $0.4 \%$ $\mathrm{NaOCl}$, while the lowest micropropagation efficiency (19.9 microshoots per one explant) was observed after 10 -minute disinfection with $0.6 \% \mathrm{NaOCl}$. This may indicate a positive influence of stress (associated with explants disinfection) on the micropropagation efficiency, which was also observed with other succulent species (Lema-Rumińska and Kulus, 2012, 2014). 
Kulus, D. (2015). Micropropagation of Kalanchoe tubiflora (Harvey) Hamet. Nauka Przyr. Technol., 9, 1, \#14. DOI: 10.17306/J.NPT.2015.1.14

Table 2. NaOCl concentration and disinfection time effect on the Kalanchoe tubiflora caulogenesis efficiency (i.e. on the number of microshoots produced from a single explant)

Tabela 2. Wpływ stężenia $\mathrm{NaOCl}$ i czasu dezynfekcji na efektywność kaulogenezy Kalanchoe tubiflora (tj. na liczbę mikrosadzonek uzyskanych z pojedynczego eksplantatu)

\begin{tabular}{|c|c|c|c|c|}
\hline \multirow{2}{*}{$\begin{array}{c}\text { Time } \\
\text { Czas } \\
(\mathrm{min})\end{array}$} & $0.2 \%$ & $0.4 \%$ & $0.6 \%$ & $\bar{x}(\%)$ \\
\cline { 2 - 5 } & $0.0 \pm 0.0 \mathrm{bA}$ & $6.7 \pm 2.2 \mathrm{aA}$ & $33.3 \pm 11.1 \mathrm{aA}$ & $13.3 \pm 3.7 \mathrm{~b}$ \\
10 & $52.6 \pm 9.3 \mathrm{aA}$ & $17.5 \pm 5.9 \mathrm{aB}$ & $20.0 \pm 6.7 \mathrm{aB}$ & $30.0 \pm 4.2 \mathrm{a}$ \\
20 & $26.3 \pm 5.7 \mathrm{~A}$ & $12.1 \pm 2.9 \mathrm{~A}$ & $26.6 \pm 5.9 \mathrm{~A}$ & \\
$\bar{x}$ & & \multicolumn{4}{|c|}{$\mathrm{NaCl}$ concentration - Stężenie NaOCl} \\
\hline
\end{tabular}

Standard deviations followed by the same letters are not significantly different at $\mathrm{p} \leq 0.05$. Small letters refer to the disinfection time, capital letters refer to the $\mathrm{NaOCl}$ concentration, $\bar{x}$ - mean.

Odchylenia standardowe oznaczone tymi samymi literami nie różnią się istotnie przy $\mathrm{p} \leq 0,05$. Małe litery odnoszą się do czasu dezynfekcji, duże litery odnoszą się do stężenia $\mathrm{NaOCl}, \bar{x}$ - średnia.

The obtained results are comparable to the micropropagation yield of the Caryophyllaceae species, which however, required the addition of both auxins and cytokinins for indirect regeneration (Holobiuc et al., 2004-2005). However, as for Crassula arborescens (Mill.) Willd. even the addition of PGRs stimulated the maximum regeneration of 13 adventitious shoots from a single leaf explant (Liu et al., 2007). Kalanchoe tubiflora was also characterised by a higher micropropagation yield than Chrysanthemum $\times$ grandiflorum Kitam. (Kulus, 2014) or Ajania pacifica (Nakai) Bremer et Humphries, which produced approximately 10 shoots from a single-node explant inoculated on a PGRs-free medium (Zalewska et al., 2012). Kane et al. (1993) achieved a significantly higher regeneration potential of single-node segments of Crassula helmsii (Kirk) Cockayne after supplementing the medium with benzyladenine (100 shoots per explant), in comparison to the cytokinin-free control (50 shoots per explant). Therefore, the addition of this compound could be considered with $K$. tubiflora. However, by using PGRs-free media, the risk of endophytes development and mutation occurrence is reduced (Vidican et al., 2009).

A problem appearing sometimes under in vitro conditions is plants vitrification (hyperhydration). It is caused by a very high level of humidity in the culture vessel $(100 \%)$ and is manifested by excessive hydration of tissues. Such plants are unable to survive. In this study, however, no such phenomenon was recorded.

After a six-month culture microshoots $5-130 \mathrm{~mm}$ in length were produced. This shows that regeneration of new plants proceeded in a continuous manner. It also highlights the possibility of using tissue culture for long-term storage of valuable $K$. tubiflo$r a$ cell lines/genotypes, especially after lowering the content of macronutrients, light intensity and/or the addition of sucrose.

\section{Rooting in vitro}

Rooting is often a separate stage of a micropropagation protocol, requiring additional transfer to an auxin-supplemented medium (Kulus and Zalewska, 2014). However, in 
the present study, it was recorded, that all of the microshoots produced roots spontaneously. Their development began after 11 days of culture. The observed rhizogenesis on a PGRs-free medium is highly beneficial. It allows for a reduction of time and costs of the procedure. Spontaneous rooting was also observed with other species (Lema-Rumińska and Kulus, 2014). These reports confirm the assumption about a high level of endogenous growth regulators in at least some succulents.

\section{Acclimatization}

Acclimatization was fully successful. A 96\% survival of microshoots was recorded. The plantlets were of a more attractive morphology (shorter internodes and more fleshy leaves) in comparison to the control plants from the greenhouse (Fig. 2).

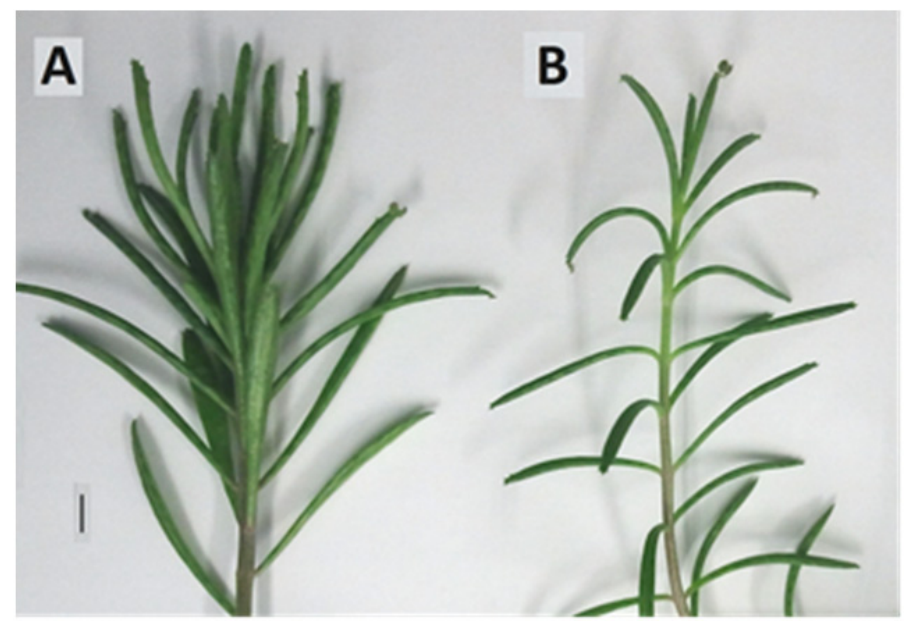

Fig. 2. Mature plants of Kalanchoe tubiflora obtained from in vitro cultures three months after acclimatization (A) and controls cultivated in the greenhouse $(\mathrm{B})(1 \mathrm{bar}=1 \mathrm{~cm})$

Rys. 2. Dojrzałe rośliny Kalanchoe tubiflora uzyskane z kultur in vitro trzy miesiące po aklimatyzacji (A) oraz kontrole uprawiane w szklarni (B) $(1$ odcinek $=1 \mathrm{~cm})$

The observed successful acclimatization is especially satisfying, since it was performed in summer (July), when it's efficiency is usually the lowest, due to low humidity, high temperatures and intense light irradiation, which significantly differ from the conditions in the growth room. It was observed that even $50 \%$ of plantlets may die at that stage, due to excessive water loss (Pérez-Molphe-Balch et al., 1998). Succulents, however, have a strongly developed cuticle and a great ability of a fast rehydration. As a result, water loss is reduced, and they are free from the desiccation shock during acclimatization (Malda et al., 1999). 
Kulus, D. (2015). Micropropagation of Kalanchoe tubiflora (Harvey) Hamet. Nauka Przyr. Technol., 9, 1, \#14. DOI: 10.17306/J.NPT.2015.1.14

\section{Conclusions}

1. Node explants of Kalanchoe tubiflora are a good explant source for micropropagation showing a high tolerance to chemical disinfection.

2. Prolonged chemical stress (treatment with $0.4 \% \mathrm{NaOCl}$ for $20 \mathrm{~min}$ ) has a positive influence on the multiplication rate of $K$. tubiflora.

3 . Both caulogenesis and rhizogenesis of $K$. tubiflora occur spontaneously on the MS medium without the addition of any plant growth regulators.

4. Microshoots of $K$. tubiflora are characterised by a high desiccation stress resistance accompanying acclimatization.

5. Micropropagation (single-node technique) can be considered as a fast and efficient reproduction method of $K$. tubiflora (over 50 microshoots from a single-node explant).

\section{References}

Garcês, H., Sinha, N. (2009). The 'Mother of Thousands' (Kalanchoë daigremontiana): a plant model for asexual reproduction and CAM studies. Cold Spring Harbor Protoc. 10. doi: 10.1101/pdb.emo133

Holobiuc, I., Paŭnescu, A., Blîndu, R. (2004-2005). Ex situ conservation using in vitro methods in some Caryophyllaceae plant species from the red list of vascular plants in Romania. Rom. J. Biol. - Plant Biol., 49-50, 3-16.

Hsieh, Y.-J., Leu, Y.-L., Chang, C.-J. (2013). The anti-cancer activity of Kalanchoe tubiflora. OA Altern. Med., 1, 2, 18-30.

Hsieh, Y.-J., Yang, M.-Y., Leu, Y.-L., Chen, C., Wan, C.-F., Chang, M.-Y., Chang, C.-J. (2012). Kalanchoe tubiflora extract inhibits cell proliferation by affecting the mitotic apparatus. BMC Complement. Altern. Med., 12, 149-159.

Johnson, E. L. (1948). A response of Kalanchoe tubiflora to X-radiation. Plant Physiol., 23, 4, 544-556.

Kane, M. E., Philman, N. L., Bartuska, C. A., McConnell, D. B. (1993). Growth regulator effects on in vitro shoot regeneration of Crassula helmsii. J. Aquat. Plant Manage., 31, 59-64.

Kulus, D. (2014). Zastosowanie kultur tkankowych w mikrorozmnażaniu chryzantem. In: J. Flizikowski (ed.), Nauka niejedno ma imię (pp. 63-72). Bydgoszcz: Wyd. UTP.

Kulus, D., Zalewska, M. (2014). In vitro plant recovery from alginate encapsulated Chrysanthemum $\times$ grandiflorum (Ramat.) Kitam. shoot tips. Propag. Ornam. Plants, 14, 1, 3-12.

Lema-Rumińska, J., Kulus, D. (2012). Induction of somatic embryogenesis in Astrophytum asterias (Zucc.) Lem. in the aspect of light conditions and auxin 2,4-D concentrations. Acta Sci. Pol. Hort. Cult., 11, 4, 77-87.

Lema-Rumińska, J., Kulus, D. (2014). Micropropagation of cacti - a review. Haseltonia, 19, 46-63.

Liu, Y., Long, Z.-L., Gao, Y., Harada, T. (2007). Organ formation and plant regeneration in vitro tissue culture of Crassula arborescens. J. Zhejiang Univ. (Agric. Life Sci.), 33, 6, 591-596.

Malda, G., Suzan, H., Backhaus, R. (1999). In vitro culture as a potential method for the conservation of endangered plants possessing crassulacean metabolism. Sci. Hortic., 81, 71-87.

Murashige, T., Skoog, F. (1962). A revised medium for rapid growth and bio assays with tobacco tissue cultures. Physiol. Plant., 15, 473-497.

Pérez-Molphe-Balch, E., Pérez-Reyes, M. E., Villalobos Amador, E., Meza Rangel, E., del Rocío Morones Ruiz, L., Lizalde Viramontes, H. J. (1998). Micropropagation of 21 species of Mexican cacti by axillary proliferation. In Vitro Cell. Dev. Biol. - Plant, 34, 2, 131-135. 
Kulus, D. (2015). Micropropagation of Kalanchoe tubiflora (Harvey) Hamet. Nauka Przyr. Technol., 9, 1, \#14. DOI: 10.17306/J.NPT.2015.1.14

Saifullah, K., Sheeba, N., Kashif, A., Samreen, Z. (2006). Direct organogenesis of Kalanchoe tomentosa (Crassulaceae) from shoot-tips. Pak. J. Bot., 38, 4, 977-981.

Vidican, T. I., Cachiţă-Cosma, D., Romocea, J.-E. (2009). The initiation of Echinocactus mihanovichii, Echinopsis chamaecereus f. lutea and Aylostera heliosa vitrocultures. Stud. Univ. Vasile Goldiş Ser. Şt. Vieţii, 19, 2, 351-357.

Wojciechowicz, M. K. (2009). Organogenesis and somatic embryogenesis induced in petal cultures of Sedum species. Acta Biol. Cracov. Ser. Bot., 51, 1, 83-90.

Zalewska, M., Antkowiak, M., Tymoszuk, A. (2012). Micropropagation of Ajania pacifica (Nakai) Bremer et Humphries with single-node method. Nauka Przyr. Technol., 6, 1, \#10.

\section{MIKROROZMNAŻANIE KALANCHOE TUBIFLORA (HARVEY) HAMET}

Streszczenie. Kalanchoe tubiflora (Harvey) Hamet to madagaskarski sukulent, będący popularną rośliną ozdobną. W związku z obecnością cennych metabolitów o działaniu antymitotycznym może być z powodzeniem wykorzystany także w terapii przeciwnowotworowej. Celem niniejszych badań było opracowanie wydajnej metody reprodukcji $K$. tubiflora. Fragmenty pędów $K$. tubiflora uzyskane $\mathrm{z}$ roślin uprawianych in vivo zdezynfekowano $\mathrm{z}$ wykorzystaniem następujących stężeń podchlorynu sodu: $0,2 \%, 0,4 \%$ i $0,6 \%$ przez 10 lub 20 min. Następnie jednowęzłowe fragmenty pędów były inokulowane na pożywce MS bez regulatorów wzrostu. Uzyskane mikrosadzonki przeniesiono do szklarni. Inicjacja kultur zakończyła się powodzeniem. Zaobserwowano regenerację mikrosadzonek. Średnia liczba roślin uzyskanych z jednego eksplantatu wyniosła od 20 do nawet 52. Mikrosadzonki wytworzyły korzenie, bez pasażowania na pożywkę ukorzeniającą. Rośliny zostały skutecznie zaaklimatyzowane do warunków szklarniowych.

Słowa kluczowe: aklimatyzacja, kaulogeneza, dezynfekcja, kultury in vitro, organogeneza, ukorzenianie, jednowęzłowe fragmenty pędów, sukulenty

Corresponding address - Adres do korespondencji:

Dariusz Kulus, Katedra Roślin Ozdobnych $i$ Warzywnych, Uniwersytet Technologiczno-Przyrodniczy im. Jana i Jędrzeja Śniadeckich w Bydgoszczy, ul. Bernardyńska 6, 85-029 Bydgoszcz, Poland,e-mail: dkulus@gmail.com

Accepted for publication - Zaakceptowano do opublikowania:

24.10.2014

For citation - Do cytowania:

Kulus, D. (2015). Micropropagation of Kalanchoe tubiflora (Harvey) Hamet. Nauka Przyr. Technol., 9, 1, \#14. DOI: 10.17306/J.NPT.2015.1.14 